Mediterranean Journal of Humanities mjh.akdeniz.edu.tr I/ 1, 2011, 43-51

\title{
Edebî Metin Çözümlemesi ve Ekoeleştiri
}

\author{
Literary Analysis and Ecocriticism
}

\begin{abstract}
Arda ARIKAN*
Özet: Yoksulluk, açlık, uçlara kayma, toplumsal cinsiyet, doğal afetler, su ve atık yönetimi gibi sorunlar artık gündelik tartışmalarımızın konuları arasına girmiştir. Oluşmakta olan bu çevre ve insan birlikteliği yeni bir ekoloji kültürüne işaret etmektedir. Çevre ve insan birlikteliğini sorun edinen araştırmalar da birbirinden farklı çözümleme yöntemleri ve bakış açılarıyla ekolojinin önemini arttırmaktadır. Gelecekte bir çalışma alanı olarak ekolojinin bir takım kırılma ve çatallanmalarla gelişmesi de beklenmektedir. İnsanların çevre sorunları hakkındaki düşünce ve daha da önemlisi yargılarının epistemolojik olarak nereden kaynaklandığı sorusu üzerinde dikkatle düşünülmesi gereken bir sorundur ki bunun yanıtı da büyük olasılıkla medya, bilim dünyası ve siyaset üçgeninde şekillenmektedir. Bireylerin düşünce, değer ve yargılarının kaynaklarının bilinmesi, öğretim ortamlarında uygulanmak üzere planlama yapılmasını ve uygulanan izlencelerden etkili sonuçlar alınmasını da kolaylaştıracaktır. Çevre eğitiminin, başta kirlilik olmak üzere diğer bütün çevre sorunlarının çözümlenebilmesinde önemli bir rol oynayacağı düşünülmektedir. Bu çalışmada ekoeleştirinin günlük okumalarımızdan bir uygulaması, okuyucuyla paylaşılacaktır. $\mathrm{Bu}$ yapılırken de ekoeleştirel yaklaşımın ne olduğu tartışmaya açılacak ve ardından da modern Türk şiirinden alınan birkaç örnek ekoeleştirel bir incelemeyle okuyucuyla paylaşılacaktır. Önerilen ekoeleştirel sorgulamanın temel amacı da bireylerin ekoeleştiriyi anlaması ve günlük yaşamda olduğu kadar sınıf ortamlarında da ekoeleştirel yaklaşımları kullanmalarını sağlamaktır.
\end{abstract}

Anahtar Sözcükler: Ekoeleştiri, çevre, eleştiri, edebiyat, ekoloji, kuram, edebiyat öğretimi

Abstract: Issues such as poverty, hunger, marginalization, gender, natural disasters and water and waste management have become our daily concerns. This newly evolving ecological culture that is shared socially will result in development of bifurcated areas of study and ideological stand points. Understanding the epistemological roots of people's everyday thoughts and judgments related to environmental issues requires careful thinking that will inevitably point at the effect of media, science, and politics. This epistemology must be cultivated so as to shape cultural and educational applications that will result in shaping the mindset of the new generations. Environmental education, in that sense, is argued to help solving environmental problems. In this present study, ecological literary criticism will be exemplified as a tool that can be used in daily readings of social and textual phenomena. While doing that, ecological criticism will be discussed and then two poems from Turkish literature are studied as an example of applying eco-criticism into our reading of literature. It is aimed that such readings will encourage individuals to apply ecological readings into textual as well as cultural texts as given in the examples within the confinement of this present paper.

Keywords: Eco-criticism, environment, criticism, literature, ecology, theory, literature teaching

Aristoteles'e göre insan bir hayvandır ve yine ona göre insan her şeyden önce "doğanın düşünerek söz sarf etmesine imkân vermiş olduğu tek hayvan" olmuştur. Aristoteles'in bu sözünden ortaya iki sonuç çıkarabiliriz. Birincisi, Aristoteles insanın hayvanlığını yani diğer bütün

\footnotetext{
* Doç. Dr., Akdeniz Üniversitesi, Edebiyat Fakültesi, Batı Dilleri ve Edebiyatları Bölümü, Antalya, ardaari@gmail.com
} 
canlı organizmalardan büyük oranda farkı olmadığını, insanın ancak dil ve siyasî düşünceye sahip olmasıyla farklılaştığını açıkça söylemekten çekinmemiştir. İkincisi ise doğa ve insan ilişkisinde doğa; veren, bahşeden, üstün durumdadır ki insana "imkân" veren odur. Aristoteles'ten bu yana insan ve doğa ilişkisi belki de birbirinden farklı binlerce benzetime, eğretilemeye ve karşılaştırmaya konu olmuştur ki insan ve hayvanın benzer tutulması bu külliyatın belki de en alışılagelmişlerinden yalnızca biridir.

Ezop'un masallarında olduğu gibi, 14. yüzyılda Anadolu Türkçesine çevrilen "Kelile ve Dimne" ve "Marzubanname" gibi eserlerde yazarlar kendilerini hayvanların yerine koyarak hayvanların ağzından konuşmakta, idarecilere bilgi, ögüt vermekte ve hikmetli sözler söylemektedirler (Özkan, 2011). Bu ve benzeri örnekler göstermektedir ki insan ve hayvan arasında birçok birliktelikler ve benzerlikler en azından felsefe ve edebiyatta hep kurulagelmiştir. Buna karşın günümüzde bir insana "hayvan" demek ya da bir kişiyi bir hayvan şeklinde resmetmek suç görülebiliyor olsa da tarihte öncü filozoflar ve yazarlar insanı bir hayvan olarak görmekten, göstermekten ve onların dilinden konuşmaktan hiç çekinmemiştir. Oysa günümüzde birçok bilimsel araştırma, insan ve maymunların benzer beyin işlevlerine sahip olduklarını ve bedenleriyle bilişleri arasında birlik olduğunu (Yalvaç, Soylu ve Arıkan, 2011) göstermektedir. Bu sonuçlar insanın bedeniyle var olduğunu yani çevresiyle etkileşiminde bedeninin onun tek aracı olduğunu göstermektedir. Aslında hepimizin bildiği gibi insan bedeni de organik olarak hayvan bedeninden ne farklıdır ne de daha üstün biyolojik özelliklere sahiptir.

İnsan ve hayvan arasındaki benzerliklere karşın, Aristoteles'ten bugüne gelirken insanı hayvan olarak görmenin nesi kötüydü de bir zamanların gerçeği bugün unutuldu bilmiyoruz. Ancak şurası kesin ki, tarihsel değişim içinde insanın yalnızca bir hayvan olarak gösterilmesinden ya da bir hayvan olarak kabul edilmesinden vazgeçilmedi. İnsanın hayvandan ya da daha doğru bir deyişle "insan olmayan varlıklardan" kopuşu hem mekân hem de vicdan boyutlarında gerçekleşti. Öyle ki insan, bir zamanlar bir üyesi olduğu "hayvanlar âlemini” kendi kurduğu "şehir" yaşamında ya "hayvanat bahçelerine" hapsetti ya da onların etini, sütünü, yumurtasını, balını hızla tüketip onları " $a v$ sporuyla" katlederek insan olduğunu yani bir hayvan olmadığını kendine ve yarattığ "uygarlığa" göstermiş oldu. Bu da yetmezmiş gibi kendinden güçsüz olan bu hayvanları, fabrika benzeri mekânlara kapatıp 1Sı ve 1şık altında sürekli yavrulatarak onların bedenlerine işkence etti ve doğada yalnızca sınırlı sayıda yavru verebilen bu hayvanları zorla hamile bıraktırarak onları özlerinden kopardı. Üretilen ve annelerinin bedenlerinden uzak yaşamaya bırakılan bu yavruları da satabilmek için onları TV reklamlarında kahkahalar atarak kesilip pakete giren tavuk ve ineklere indirgedi. Bu yağmacı ve gaddar tutum bugün sanal dünya denilen internet ortamında da görülmektedir. Örneğin, internette bir arama motoruna "tavuk" anahtar sözcüğü girilip görsel araç araması yapıldığında görülecektir ki çıkan görsel araçların ezici bir çoğunluğu pişirilip kızartılmış tavuk parçalarının resimleridir. Kısaca söylemek gerekirse bir zamanlar bir can olan, yumurtasından civcivinin çıkması sevinç nedeni olan tavuk şimdi paketlenmiş bir gıda maddesinden başka bir anlam taşımaz olmuştur günümüz "uygarlaşmış" şehir insanı için.

İnsanın doğayla olan ilişkisinde doğada bulunan tüm canlı ve cansızları vahşîce tüketip tahrip etmesi salt bedenî istek ve gereksinimlerinden kaynaklanmamaktadır. Aksine, bir takım dinî buyruk, kurum ve metinlerde de insanın doğanın sahibi olduğu sanısı kanunlaştırılmaktadır. Leiss (1984) insanın, doğaya egemen olması kavramının 17. yüzyılın başlarına ve özellikle de Bacon'a kadar gittiğini belirtirken bu kavramın incelenmesinin özellikle "teknolojik gelişmenin toplumsal etkilerinin daha iyi anlaşılması için uygun bir temsil" olacağını söylemektedir (32). Leiss'ten farklı olarak Ruekert (1996) doğaya egemen olma düşüncesini Hristiyanlığın ortaya çıkışına kadar götürür ve ona göre Hristiyanlık yeryüzünün en fazla "insan merkezli" dini olmuştur. Buna göre, insanın doğayı dilediği gibi sömürmeye hakkı vardır ve bu hak ona Tanrı tarafından verilen bir armağandır. Bununla birlikte insan, bir zamanlar en azından felsefî olarak 
bir üyesi olduğunu varsaydığı hayvanları katlederek insan olmadı. Daha da ilginci, insan kendine en çok benzeyenleri de sınıflayarak kendi alt türlerini de hiyerarşik bir toplumsal yapı haline getirdi. Böylelikle insanlar, kendinden farklı kültür, değer ve yaşam koşullarına sahip farklı insan gruplarını aynen hayvanlara yaptığı gibi kullanma hakkını kendinde gördü. Opperman'ın (2007) belirttiği gibi toprakların yerüstü ve yeraltı zenginliklerini Batı'ya taşıyan beyaz tüccarlar kadar Bacon, Lewis Roberts ve Robert Boyle gibi İngiliz düşünürler mekanik bir dünya görüşünü savunup yayarak ve İngiliz romancıları da eserleriyle bu emperyalist ideolojiyi meşrulaştırırcasına ırkçı betimlemeler yaparak dünyayı bu günlere getirdi. Kısaca söylemek gerekirse insan, hayvan ve toprağıyla doğanın tümünün kıyımına düşünsel ve bedensel olarak destek verdi. İnsanların insan ve hayvanları köle etmesi, onları bedenen ve ruhen sömürmesi, onlara tecavüz etmesi, öldürmesi veya dilediği gibi doğurtması ve öldürmesi (aynı fabrikalarda boğazlanan tavuklara yaptığı gibi) işte bu mekanik dünya görüşünün sonuçlarındandır diyebiliriz. Buna karşın, Drew ve Sitter'in (2011) belirttiği gibi insan olmayan varlıkların yaşamlarına değer veren birçok 18. yüzyıl yazar ve şairi bulunmakta ancak onların dili elbette ki ne bizim gündelik dilimize ne de ekoeleştirinin diline benzemektedir. Bu yüzyılın yazar ve şairleri doğal yaşamla ilgili sürekli bir sorgulama, geliştirme ve yenileme çabasını elden bırakmamış Romantik döneme ait bir grubu oluşturmaktadır.

\section{Çevre ve İnsan}

Buraya kadar insan ve doğa ilişkisini kısa ve eleştirel bir üslupla özetlerken görebiliriz ki, insan ve çevre ilişkisi tarihsel süreç içerisinde aslında birbirinden ayrılamaz bir birliktelik taşımaktadır. Wang'ın (2009) da ifade ettiği gibi "çevre" terimi günümüzde hem doğal çevreyi hem de insanın şehirleşmiş yaşamında onu çevreleyen fiziksel çevreyi içermektedir. Vital'a (2005) göre biyolojinin bir çalışma alanı olan çevrebilim kendine özgü bir grup sorular (farklı türlerin oluşturdukları gruplar ve toplulukların nüfusları, özellikler, habitatları v.s.) sormakta ve bu sorulara yanıt veren bir grup bilimsel çalışmaya da destek olmaktadır. Örneğin yoksulluk, uçlara kayma, toplumsal cinsiyet, su ve atık yönetimi gibi sorunlar aynı zamanda son dönem ekoloji tartışmalarının konuları arasına girmiştir ki bütün bu başlıklar çevresel adalet kavramı içinde sorgulanabilmektedir. Oluşmakta olan bu yeni ekoloji kültüründe birbirinden farklı çözümleme yöntemleri ve bakış açılarıyla özne duruşları ekolojinin önemini artıracak ve bir çalışma alanı olarak ekolojinin bir takım kırılma ve çatallanmalarla gelişmesini sağlayacaktır.

Heise'e $(2008,25)$ göre kavramsal farklı1ıklarına rağmen ortaya çıkmış tüm ekolojik görüşlerin temelinde "yeryüzünde yaşayan insanların kültürel farklıllklarına bakılmaksızın küresel bir ekosistemi paylaştıkları" herkes tarafindan kabul edilmesi gereken bir gerçektir. Ancak, gezegenimize atfettiğimiz bütün bilişsel, duyuşsal ve dilsel terimlerin biyolojiyle ne şekilde ilintili olduğu sorgulanmalıdır. Örneğin, bir grup bilim insanı (iktisatçı ve nüfus çalışmacıları başta olmak üzere) sanayici ve işadamlarıyla ağız birliği ederek "kapitalist ekonomik sistemin doğayı kirlettiği kadar kirliliğe çözüm de bulacağını" iddia etmekten çekinmemektedir (Garrard, 2004, 16). Bu görüşteki insanlara göre radyoaktif atık sorununu ortaya koyan insan elbette bu sorunun çözümünü de bulacaktır.

Günümüzde iklim değişikliğini konu edinen edebî eserlerin, film ve belgesellerin sayısı artmıştır (Heise, 2008, 208). Örneğin 2000'li yıllarda iklim değişikliğini konu edinen filmler Ice Age gibi animasyon filmlerden Absolute Zero, Ice Twisters, Meltdown: Days of Destruction ve Arctic Blast gibi geniş bütçeli Hollywood filmlerine uzanmaktadır (Films About Disasters, t. y.). İklim değişikliği gibi hayati önemi bulunan sorunları işleyen eserlerin insanlar tarafindan üretilmesi ve izlenmesi, insanların yaşadıkları çevre sorunlarını kültürel yaratımlarına aktardıklarını göstermektedir. Buna karşın, insanların çevre sorunları hakkındaki düşünce ve daha da önemlisi yargılarının epistemolojik olarak nereden kaynaklandığ 1 sorusu üzerinde dikkatle düşünülmesi gereken bir sorundur ki bunun yanıtı da büyük olasılıkla medya, bilim dünyası ve siyaset üçge- 
ninde şekillenmektedir. Bireylerin düşünce, değer ve yargılarının kaynaklarının bilinmesi, öğretim ortamlarında uygulanmak üzere planlama yapılmasını ve uygulanan izlencelerden etkili sonuçlar alınmasını da kolaylaştıracaktır. Çevre eğitiminin, başta kirlilik olmak üzere diğer bütün çevre sorunlarının çözümlenebilmesinde önemli bir rol oynayacağı düşünülmektedir.

\section{Ekoloji Bilgisinin Gündelik Okumalara Uyarlanması}

İnsanın bir ürünü olduğu kadar aynı zamanda onu şekillendiren bir araç da olan edebiyat, kuramsal olarak birçok farklı yöntemle yazılı ve sözlü metinleri çalışan bir disiplindir. Örneğin Marksist kuram edebî eserleri incelerken toplumsal sınıfi, Feminist ve Queer kuramlar toplumsal cinsiyeti, Formalist kuram da edebî eserin şekilsel olarak işleyişini bilimsel bir sorun olarak ele almıştır. Benzer olarak ekoeleştiri de insan ve çevreyi sorun olarak almıştır diyebiliriz. Glotfelty (1996, xix) ekoeleştiriyle edebiyatın ilişkisi nedir sorusuna "ekoeleştiri en basit anlamıyla edebiyat ile fiziksel çevre iliş̧isinin çalışılmasıdır" diyerek yanıt vermekte ve eklemektedir: "Nasıl ki feminist eleştiri dil ve edebiyatı toplumsal cinsiyet bilinciyle çalışıyorsa ve Marksist eleştiri edebî metinlere üretim şekilleri ve ekonomik sinıf bilinciyle yaklaşlyorsa ekoeleştiri de edebî çalışmalara yerküre merkezli yaklaşmaktadır". Opperman'a (1996) göre ekoeleştiri doğa ve çevre olgularıyla edebiyat arasındaki ilişkileri inceleyen yeni bir eleştiri akımı olarak ortaya çıkmıştır ve edebî metinleri ekolojik bilinçlenme çerçevesinde ele alarak metinleri ekoeleştirel bir bakış açısıyla tartışmaktadır. Bulut'a (2005) göre örneğin, George Orwell, Coming Up For Air adlı eserinde hızlı kentleşme ve endüstriyel gelişmelerin doğal çevreyi yok edici etkilerini yansıtmıştır ki böylesi bir eleştiri ancak ekoeleştiriyi temel olarak alan bir bakış açısıyla olasıdır. Wang'ın (2009, 290-291) da Glotfelty'den (1996) aktardığ gibi eko-eleştirmen ve eko-kuramcılar aşağıda belirtilen sorulara yanıt aramaktadırlar (çeviri makalenin yazarına aittir):

Doğa bu sone'de nasll gösterilmiştir? Fiziksel mekânın bu romanın olay örgüsündeki rolü nedir? Bu oyunda yer alan değerler ekolojik erdemle uyumlu mudur? Toprakla ilgili ĕgretilemelerimiz (metaforlarımız) ona nasıl davrandı̆̆ımıza ne şekilde etki eder? Doğa yazımının bir edebi tür olarak özellikleri nelerdir? Irk, sinif, cinsiyete ek olarak yer [yazarların vurgusu] yeni bir eleştirel kategori olabilir mi? Erkekler doğa hakkında kadınlardan farklı mi yazmaktadırlar? Okuryazarlık insanların doğal dünyayla olan ilişkisini hangi yollarla etkiler? Vahşi yaşam kavramı zaman içinde nasıl değişmiştir? Çevre krizleri günümüz edebiyatına ve popüler kültürüne hangi yollarla sızmakta ve etkisi nasıl olmaktadır? Amerikan hükümetinin raporlarına, şirket reklamlarına televizyonda yer alan doğa belgesellerine hakim olan (onlar bilgilendiren ya da şekillendiren) doğa görüşü ve bunun retoriksel etkisi nedir? Ekoloji biliminin edebi çalışmalar üzerindeki etkisi nedir? Bilim, edebiyat incelemesine ne şekilde açıktır? Edebiyat çalışmaları ve çevre söylemleri ile tarih, felsefe, psikoloji, sanat tarihi ve etik gibi disiplinler arasinda karşıllklı etkileşimler ne şekilde olasıdır?

Yukarıda verilen sorular eko-eleştirmen ve eko-kuramcıların ellerinde nicelik ve nitelik olarak artacaktır. Örneğin, Bender (2008) "edebî metinlerde yer alan belirli yaşam formları birer imge olarak içinden çıktığı kültürün tarihsel süreci ve bugünü ile nasıl ilintilendirilebilinir?" gibi edebî metin, doğal yaşam formları ve insan kültürünün tarihsel gelişimi üçlüsünü kapsayan bir soruya yanıt aramaktadır. Diğer bir deyişle, edebi metinlerde yer alan asma ağacı, kedi, köpek, kartal, yılan, balina, kelebek ve bunlar gibi daha birçok yaşam formu aslında insanlık tarihinin çevreyle kurmuş olduğu kültürel birliktelik hakkında bize ipuçları vermektedir. Dolayısıyla Opperman'1 (1996) doğrular şekilde böyle bir soruya yanıt arayan biri edebiyat eserlerinde ekolojik temaların ve doğa ile ilintili sembollerin kullanımı üzerine yoğunlaşmalı ve bu süreçte 
hem sosyal bilimlerden hem de biyoloji gibi doğa bilimlerinden de yararlanmalı ve bu bilimlerde geliştirilen kavramları edebiyat kuram ve çözümlemelerinde kullanmalıdır. Yine Opperman'a (2009: 5) göre “Ekoeleştirmenler doğanın insan tarafindan ötekileştirilmesini, insanın kendisini doğadan ayrı bir konumda değerlendirmesini ve doğanın hammadde kaynă̆ olarak bilinçsizce sömürülmesini eleştirirler". Gündelik yaşam pratiğinde de görebiliriz ki yeni inşa edilen ve yüzlerce konuttan oluşan sitelerin taciz ettiği doğal çevrede bulunan kayaların konut yapımında yerlerinden sökülerek kullanılması orayı mesken tutmuş tilkilerin yuvasız kalmalarına neden olmakta ve korunmasız kalan tilkiler de göç yollarında ölmektedir. Kısaca insan, çevresini etkilemektedir ve çevresel bir bakış açısı insana doğada meydana getirdiği değişiklikleri gösterecek yani ona çevresiyle olan ilişkisini gösteren bir ayna tutacaktır.

$\mathrm{Bu}$ çalışmada şimdi ekoeleştirinin günlük okumalarımızdan bir uygulaması okuyucuyla paylaşılacaktır ancak bunu yaparken amacın yazar ve şairleri karalamak ya da onların eserlerinin edebî değerini küçümsemek olmadığı bilinmelidir. Ekoeleştiri bir edebî kuram olarak iyi eser- kötü eser ayrımıyla ilgilenmez. Ekoeleştirinin amacı, yukarıda da belirtildiği gibi, edebi eserleri çevre bilinci oluşturma sürecinde ele almaktır.

\title{
Ekoeleştirinin Uygulanması
}

İnsan ve dünya birbirinden ayrılabilir mi? Daha açı bir ifadeyle dünya ve insan birbirlerinden ayrı iki nesne ya da olgu gibi değerlendirilebilir mi? Aşağıdaki sorulara yanıtlarımız neler olabilir?

"Dünyayı alıp verebilir miyiz?

"Dünyayla oynamak olası mıdır?”

"Dünyay birileri elimizden alabilir mi?"

"Insan mı dünyaya dünya mı insana bir şeyler ‘ögretir'?”

"Insanın dünyaya ögretmesi gerekenler nelerdir?"

"İnsan doğayla ya da güneş gibi varlıklarla savaşır mı? Neden?"

$\mathrm{Bu}$ ve benzeri sorulara verdiğimiz olumlu yanıtlar aslında insanın doğayı kendisinin dışında var olan bir nesne/olgu olarak gördüğünü göstermektedir ki Türk Modern şiirin birçok örneğinde insanların doğaya dilediklerini yaptıkları yani dünyanın insan için bir araç olduğu görülmektedir. Örneğin, Nazım Hikmet'in "Dünyayı Verelim Çocuklara" başlıklı şiirinde dünya ve onun parçası olan elma, ekmek ve ağaç insanlar tarafından alınıp verilecek birer nesne olarak görülmekte ve dünya alınıp verilen bir nesne olmanın dışında "öğrenen" rolüne indirgenerek insanın dışında bir olgu ya da onun bir malzemesi olarak algılanmaktadır:

\author{
Dünyayı verelim çocuklara hiç değilse bir günlüğüne \\ all pullu bir balon gibi verelim oynasinlar \\ oynasınlar türküler söyleyerek yıldızların arasında \\ dünyayı çocuklara verelim \\ kocaman bir elma gibi verelim sicacık bir ekmek somunu gibi \\ hiç değilse bir günlüğüne doysunlar bir günlük de olsa ögrensin dünya \\ arkadaşlı̆̆ \\ çocuklar dünyayı alacak elimizden \\ ölümsüz ă̆açlar dikecekler.
}

Merchant'ın (1992) belirttiği gibi Rönesans'ın tabiatı merkeze alan dünya görüşü yerine ortaya konulan ve erken dönem kapitalizmin bir görünümü olan mekanik dünya görüşü, tabiatın kontrol edilebilir olmasını ve insanın doğaya egemen olmasının "doğallı̆̆ını" da dile getirmekteydi. Benzer bir şekilde, "Güneşi İçenlerin Türküsü” başlıklı şiirinde Nazım Hikmet, duygu dolu ve belki de sembolik bir anlatımla insan ve güneşten birer düşmanmışçasına bahsetmekte ve insanlara doğa güçleriyle savaşan birer kahramanlarmış gibi hücum etmeyi önermektedir. Popüler kültürde çeşitli şarkı formlarında da seslendirilmiş olan şiir aşağıdaki gibidir (Akın var 
48

güneşe akın [Video File]):

\author{
Akın var \\ Güneşe akın! \\ Güneşi zaptedeceğiz \\ Güneşin zaptı yakın!
}

Orhan Veli'nin bir bahar gününü tasvir ettiği "İstanbul'u Dinliyorum" başlıklı şiirinin aşağıda verilen kısmında insan, İstanbul'da ya doğal ve insan yapısı olan bütün çevreyle bütünleşmekte olan varlık olarak betimlenmiş ya da bütünü dinleyen bir parça olarak çevresinden soyutlanarak bir gözlemciye ya da kayıt cihazına indirgenmiştir. Zülfü Livaneli'nin sesinden de şarkı formunda dinlenebilen şiir aşağıdaki gibidir (Zülfü Livaneli- İstanbul'u dinliyorum gözlerim kapalı [Video File]):

$$
\begin{aligned}
& \text { İstanbul'u dinliyorum, gözlerim kapalı } \\
& \text { Önce hafiften bir rüzgâr esiyor } \\
& \text { Yavaş yavaş sallaniyor } \\
& \text { Yapraklar, ağaçlarda; } \\
& \text { Uzaklarda, çok uzaklarda, } \\
& \text { Sucuların hiç durmayan çıngırakları } \\
& \text { İstanbul'u dinliyorum, gözlerim kapalı } \\
& \text { İstanbul'u dinliyorum, gözlerim kapalı } \\
& \text { Kuşlar geçiyor, derken } \\
& \text { Yükseklerden, sürü sürü, çı̆̆glk çı̆̆lık. } \\
& \text { A ğlar çekiliyor dalyanlarda } \\
& \text { Bir kadının suya değiyor ayakları } \\
& \text { Istanbul'u dinliyorum, gözlerim kapalı } \\
& \text { Istanbul'u dinliyorum, gözlerim kapalı } \\
& \text { Serin serin Kapalıçarsı } \\
& \text { Clvol covıl Mahmutpaşa } \\
& \text { Güvercin dolu avlular } \\
& \text { Çekiç sesleri geliyor doklardan } \\
& \text { Güzelim bahar rüzgârinda ter kokuları } \\
& \text { Istanbul'u dinliyorum, gözlerim kapalı } \\
& \text { Istanbul'u dinliyorum, gözlerim kapalı } \\
& \text { Başımda eski âlemlerin sarhoşluğu } \\
& \text { Los kaylkhaneleriyle bir yalı } \\
& \text { Dinmiş lodosların uğultusu içinde } \\
& \text { Istanbul'u dinliyorum, gözlerim kapalı }
\end{aligned}
$$

$\mathrm{Bu}$ şiirde geçmekte olan "sucuların hiç durmayan çıngırakları, ağlar çekiliyor dalyanlarda, bir kadının suya değiyor ayakları, çekiç sesleri geliyor doklardan, loş kayıkhaneleriyle bir yalı" gibi tamlamaları artık hangi İstanbul yaşayanına bir anlam ifade edebilir? Ya da daha öz bir anlatımla, sucu çıngıraklarının sesleri, dalyanlar, denizle birleşebilen vücutlar, doklarda çalışan insanlar ve kayıklara ayrılmış yerleri olan yalılar İstanbul'da yaşayan genç nesillerin günlük gerçekliğiyle ne kadar ilintilendirilebilir acaba? Ancak Orhan Veli'nin 1950 yılında Ankara'da bir akşam vakti sokakta belediye'nin açtırdığı bir çukura düşüp başından yaralanmış olduğu ve bir kaç gün sonra da beyin kanaması sonucu yaşamını yitirmesi, belediyelerimizin çalışmalarını yakından takip eden bütün vatandaşlarımıza mantıklı gelebilecek kötü bir tesadüf sayılabilir. Belediyelerin yetersiz çalışmaları halen hepimiz tarafından eleştirilebilmektedir. Oysa İstanbul'da artık ne sucu çıngırakları duyulabilmekte ne de insanlar denize rahat rahat girebilmektedir. 
Şiirin ekoeleştirel bir çözümlemesi öyleyse İstanbul'daki değişimi gözler önüne sermekte, doğanın tahrip edildiğini ve birçok insani deneyimin aradan geçen yıllar içinde yok olduğunu gösterebilmektedir. Öyleyse ekoeleştiri yoluyla edebiyatı çalışmak, insanları tarihsel akışla buluşturmakta ve insanı zaman ve mekânla sarmalayarak merkezini herhangi bir metnin oluşturduğu yaratıcı ve hassas (duyarlı) bir okuma ve düşünme sürecine dâhil etmektedir.

Ekoeleştirel bir yaklaşım aynı zamanda metinlerde geçen yerel kültürlerin ve dillerin bugünkü durumlarını anlamamıza da dilbilimsel eleştiri ve etimoloji gibi yardımcı olabilmektedir. Örneğin, Mıgırdiç Margosyan'ın öyküleri Ermeni ve Hristiyanlık ların içinde yaşadığı bir Güneydoğu Anadolu portresi çizerken, günümüzde böyle bir toplumsal yapıyı görmek hemen hemen mümkün değildir. Benzer olarak 1960'lardan önce, içinde Türklerin yaşadığı, kişilerinden bir kısmının Türk olduğu bir Alman romanı bulmak zorken bugün birçok Alman ve Türk yazarın Almanca yazdıkları romanlarda Türk kişiler görülmektedir. Dolayısıyla edebiyat doğal ve toplumsal çevreye hem şahitlik etmekte hem de okuyucuyu toplumsal yaşam hakkında bilinçlendirmekte ya da en azından bilgilendirmektedir.

Her şeyden önce ekoeleştiri aynı zamanda dilin geçirdiği değişime de duyarlı bir şekilde yaklaşabilmektedir. Bundan 50 ya da 60 yıl önce yazılmış metinlerin bugünkü gençler tarafından anlaşılamıyor olması, yine zaman içinde görülen değişimin boyutlarını göz önüne sermektedir. Örneğin 17. yüzyıl şairlerinden "Benim ol Nef' $\imath$ - $i$ ruşen-dil ü safgevher/ Feyz alır cam-i safa meşreb-i bi-bakimden" diyen Nefî’yi (1985) anlamakta zorlanan günümüz insanı yine 17. yüzyıl ozanı olan Karacaoğlan'ın “ ̈U̧ derdim var birbirinden seçilmez- Bir ayrllık bir yoksulluk bir ölüm" dizelerini anlayabilmektedir ki aslında insanın kültürel çevresine de duyarlı bir ekolojik kuram çalışması hem toplumsal ve kültürel çevrenin dille olan ilişkisini anlamamıza yardımcı olabilmekte hem de dilin tarihsel gelişimini anlamamız için canlı örnekler sunabilmektedir.

Burada dilde tutucu bir yaklaşımı özendirmek değil, tam aksine dildeki değişime okuyucunun duyarlı bir şekilde yaklaşmasını sağlayarak yaşanan değişikliklerin okuyucu tarafından algılanmasını ve gereken yerde okuyucunun tavır almasını sağlamak için ona dinamik ve etkin bir aktör olduğunu hatırlatmaktır. Eğer bugünün okuyucusu elli yıl önce yazılmış olan bir şiirde geçen bazı sözcükleri anlayamıyorsa, bu anlamama hali o şiirde yer alan doğal ve insan yapısı çevreyi de anlayamamasıly eş zamanlı olabilmektedir.

\section{Sonuç}

Ekoeleştirinin edebî metinlerin incelenmesinde, farklı edebî tür ve metinlere hatta gündelik yaşamın farklı pratiklerinin yorumlanmasında kullanılması olasıdır. Örneğin, Andrews (2008) Osmanlı gazeli hakkındaki bir incelemesinde, gazeli kültürel olarak oynanan bir oyun olarak ve ekolojik bir bakış açısıyla dört temel açıdan inceler ki bunlar etkinlik, mekan, katılanlar ve kurallardır. Etkinlik kavramının aslında diğer üç özelliği kapsadığını düşünen yazar gazelde anlamı, bir gazelin organik işleyişini; gazelde yazılanlarla ve gazelin yazıldığı yakın çevrenin ilişkilendirmesinde arar. Kısaca Andrews'a (2008) göre bir metnin anlamı bir edebî metnin anlatısal içeriği ile bu içeriğin gerçek yaşamda yaşanılan izdüşümünün ya da gölgesinin bir oyun şeklinde ele alınmasıyla ortaya çıkmaktadır. Buradan da anlaşılabilir ki ekoeleştirel okumalar aslında metin merkezli ve okuyucu merkezli okumaların kesişiminden oluşur, hatta metin ve okuyucunun deneyimini çevre bağlamında ele alarak onu yeniden ve bu sefer çevresel sorunlar bağlamında üretir. Hitt'in (2004) de belirttiği gibi aslında ekoeleştiri edebi metinlerde doğanın insan kültürleri tarafından sömürülmesini ve tüketilmesini temel alarak yargılarda bulunma eylemidir ve bu yönüyle de ekoeleştirel yazmak demek bu tarz değer yargılarını edebi metinlerle ilişkilendirerek yazmak demektir.

Yukarıda ekoeleştirinin gündelik yaşamın farklı pratiklerinin incelenmesinde de kullanılabileceğini belirtilmiştir. Örneğin, ekoeleştirinin uygulanabileceği gündelik hayata en yakın pratik, 
aile fotoğraflarına bir göz atmaktır diyebiliriz. Çoğumuz anne, baba ve dedelerimizin eski fotograflarına bakıp sorular sorar ve hatta güleriz. Ancak o fotoğraflar aynı zamanda değişen çevremizin resmîleşmemiş belgeleridir. Bir romanda geçen "gramofon" ya da "triportör" sözcüklerinin anlamını bilmeyen bir okuyucu aslında o alet ya da taşıtı gördüğünde de ne olduğunu, ne işe yaradığını ve onlarla ilintili sınıfsal, kültürel ve toplumsal etiketleri de anlayamamaktadır. Okuyucunun kendi fiziksel çevresinden yitip gitmiş aletler, taşı1tlar, görüntülerdir artık bunlar. Kısaca insanın çevresi hem araç, hem söz, hem de anlam olarak değişmiştir.

Bu çalışmanın başında Wang'ın (2009) da belirttiği gibi çevre kavramının doğal çevre ve fiziksel çevre olarak ikiye ayrılabileceğinden hareketle, insanın şehirleşmiş yaşamının ona yeni bir çevre sunduğundan bahsedilmişti. Bu şehirleşmiş yaşam Gerbner'e (1992) göre yeni bir aile ve eğitim tanımı da ortaya koymaktadır. İnsanlık tarihinde ilk kez bir insan günlük kültürel çevresinde ailesi, okulu, ibadethanesi, komşuları ve hatta kendi anavatanı olmadan doğup büyüyor. Yazara göre her dört Amerikalıdan üçü onunla ilgilenecek bir ebeveyni olmadan, buna karşın günde ortalama yedi saat televizyon seyrederek ve dolayısıyla atalarının değer ve öyküleri yerine medyanın değer ve anlatımlarıyla büyüyor. Kısaca çevre etmeni 21. yüzyıl insanının kültürel çevresinin değişime uğramış olduğu tümsel bir alanı ve bu alanın içinde yer alan tüm araçları içermektedir ki ekolojik eleştiri, en azından edebiyat metinlerini, çevre etmeni açısından incelememizi ve geçmişten günümüze yaşadığımız değişimi gözler önüne sererek geleceğimiz hakkında da tahminler yürütmemizi kolaylaştırmaktadır. Belki de ilk defa bir edebiyat kuramı geleceğimizin nasıl şekilleneceğini bu kadar yoğun ve kapsamlı bir şekilde irdelemektedir. Ekolojik eleştiri metinleri toplumsal sınıf ya da cinsiyet gibi sınırlı kategorilerle değil, insanı çevreleyen yaşamın tümü bağlamında ele almaktadır. Sözün kısası ekolojik eleştiri, 21. yüzyıl insanı için önemli bir kavram ve yararlı bir araç olup bireylerin onu almasını ve bütün evrenin yararına kullanmasını beklemektedir.

$\mathrm{Bu}$ çalışmada çevresel bir kuram ile gündelik yaşamı, müziği, sanatı, edebiyatı, ulaşım, kirlenme, suç ya da her hangi bir olguyu ya da aracı incelemenin yüzeysel ancak uygulamalı bir örneği verilmiştir. Doğal çevre kavramı bile doğal çevre zevki ile oluşmaktadır çünkü Kates'in (1984) Lowenthal ve Prince'den $(1955,186)$ aktardığına göre "her ülkenin insanı, toprağını seçilmiş ve alışılmış gözlükler ile görür ve gördüğü gibi yeniden üretmeye çalışır" (247). Dolayısıyla nasıl bir doğa ya da çevre istediğimiz aslında nasıl bir insan yetiştireceğimizle ilgilidir. İnsanlar çevrelerini kültürel olarak görmeyi öğrenir ve gördüğünü de yeniden üretir. Çevreye ve çevre sorunlarına duyarlı bir şekilde ve sorunlara eğilerek bakan bireyler o sorunları çözmek için çevrelerine bakacaklar ve aslında kendilerinin çevreden ayrı olmadıklarını, bilakis insanın kaderinin çevresinin kaderiyle aynı olduğunu fark edecektir. Çevresel sorunları çözmek için de Spooner'ın (1984) belirttiği gibi doğa bilimleri ile toplum bilimleri arasında gerçek bir diyaloğun başlatılması gerekmektedir. İşte ekolojik kuram, en temelde toplum bilimlerinden biri olan edebiyatla doğa bilimlerindeki bilgilerin tartışıldığg ve bir yöntem olarak sunulduğu bir diyaloğun örneği ve alanıdır. İşte bu yüzden yeni kuşakların ekolojik kuramla bilinçlendirilmesi çevre ve onun bağlamında yaşayan toplumun en önemli gereksinimlerinden biridir. 


\section{KAYNAKÇA}

Akın var güneşe akın [Video File]. http://www.youtube.com/watch?v=IoAVpJmJTrM

Andrews, W. G. (2008). Şiirin sesi. Toplumun Şarkisı. İstanbul: İletişim.

Aristo. Politics (trans. Benjamin Jowett). http://classics.mit.edu/Aristotle/politics.1.one.html

Bender, M. (2008). Tribes of snow: Animals and plants in the Nuosu Book of origins. Asian Ethnology, $67(1), 5-42$.

Bulut, D. (2005). An Ecocritical analysis of George Orwell's Coming up for air. Hacettepe Üniversitesi Edebiyat Fakültesi Dergisi, 22(1), 237-248.

Drew, E. ve Sitter J. (2011). Ecocriticism and eighteenth-century English studies. Literature Compass, $8(5), 227-239$.

Films About Disasters. (t.y.). In Wikipedia. 13 Nisan 2011 tarihinde alınmıştır: http://en.wikipedia.org/wiki/List_of_disaster_films

Garrard, G. (2004). Ecocriticism. Oxfordshire: Routledge.

Glotfelty, C. (1996). Introduction. In C. Glotfelty \& H. Fromm (Eds.), The Ecocriticism reader: Landmarks in literary ecology. London: University of Georgia Press.

Gerbner, G. (1992). The cultural environment movement. Access! Manhattan, 2(1), 4-5.

Heise, U. K. (2008). Sense of place and sense of planet: The environmental imagination of the global. New York: Oxford University Press.

Hitt, C. (2004). Ecocriticism and the long eighteenth century. College Literature, 31(3), 123-147.

Kates, R. W. (1984). Çevrenin insanlarca algılanışı. Yerleşim ve çevrebilim sorunları: Kuram ve uygulama (Uluslararası sosyal bilimler dergisinden seçmeler: (2), 240-256.

Leiss, W. (1984). Ütopya ve teknoloji: İnsanın doğaya egemen olması konusunda düşünceler. Yerleşim ve Çevrebilim Sorunları: Kuram ve Uygulama (Uluslararası Sosyal Bilimler Dergisinden Seçmeler: (2), 31-46.

Lowenthal, D. ve Prince, H. C. (1964). English landscape tastes. Geographical Review, 54, 309-346.

Merchant, C. (1992). Radical ecology: The search for a livable world. New York: Routledge.

Nef'î. (1985). (Hazırlayan: Abdülkadir Karahan). Nef'î divanı'ndan seçmeler. Ankara: Kültür ve Turizm Bakanlığı Yayınları.

Opperman, S. (1996). Ecocriticism: Natural world in the literary viewfinder. Hacettepe Üniversitesi Edebiyat Fakültesi Dergisi, 16(2), 29-46.

Opperman, S. (2007). Ecological imperialism in British colonial fiction. Hacettepe Üniversitesi Edebiyat Fakültesi Dergisi, 24(1), 179-194.

Opperman, S. (2009). Ekoeleştiri. PEN Panel: Doğa ve edebiyat. 17 Nisan. http://www.pen.org.tr/files/ GreenPEN\%20Ekoele\%C5\%9Ftiri\%20Prof.\%20Dr.\%20Serpil\%20Opperman.pdf

Özkan, M. (2011). Eski Anadolu Türkçesi döneminde ortaya konan tercümelerin Türk diline etkisi. Dil ve Edebiyat Araştırmaları Dergisi, 3, 1-64.

Ruekert, W. (1996). Literature and ecology. Cheryll Glotfelty \& H. Fromm (Eds.), The Ecocriticism reader. London: University of Georgia Press.

Spooner, B. (1984). Çevrebilim araştırmalarının insan içeriği. Yerleşim ve Çevrebilim Sorunları: Kuram ve Uygulama (Uluslararast Sosyal Bilimler Dergisinden Seçmeler, (2), 275-296.

Vital, A. (2005). Situating ecology in recent South African fiction: J. M. Coetzee's The Lives of Animals and Zakes Mda's The Heart of Redness. Journal of Southern African Studies, 31(2), 297-313.

Wang, N. (2009). Toward a literary environmental ethics: A reflection on eco-criticism. Neohelicon, 36, 289-298.

Livaneli, Z. (t.y.). İstanbul'u dinliyorum gözlerim kapalı [Video File]. http://www.youtube.com/watch?v= EQSFvLRPGLs 